\title{
The Business Performance of Vietnam's Commercial Banks
}

\author{
NGUYẼ̃N TH!̣ LOAN
}

Banking Uninversity

Email: loan.dhnh@gmail.com

TRẦ THỊ NGỌC HẠNH

Eximbank

Email: tranngochanh0405@gmail.com

\begin{tabular}{cl} 
ARTICLE INFO & ABSTRACT \\
\hline $\begin{array}{c}\text { Analyzing the business performance or efficiency of commercial } \\
\text { Received: }\end{array}$ & $\begin{array}{l}\text { banks plays an important role in enabling bank executives to make } \\
\text { Marganizational decision and policies that may facilitate the }\end{array}$ \\
$\begin{array}{c}\text { Received in revised form } \\
\text { profitability and enhance the bank's performance. In this paper, the }\end{array}$ \\
$\begin{array}{c}\text { March 29, 2013 } \\
\text { authors employ multiple methods to evaluate the business } \\
\text { June 15, 2013 }\end{array}$ & $\begin{array}{l}\text { performance of Vietnam's commercial banks and extend some } \\
\text { suggestions for applying analyzing methods and improving their } \\
\text { performance. }\end{array}$
\end{tabular}

Keywords:

business performance

efficiency

commercial banks 


\section{INTRODUCTION}

The business performance or efficiency is one of the top issues of bank executives because it is directly related to the sustainable profit and the banking efficiency, and ensures the bank competitiveness in the context of the international economic integration. Analyzing the business performance has been regularly and periodically conducted by Vietnam's commercial banks, which is mainly based on indices. Thus, in this paper, besides the financial index-based analytical method, factor analysis is also employed to estimate the business performance of Vietnam's commercial banks; and suggestions for perfecting and enhancing it are extended.

\section{THEORETICAL BACKGROUND}

According to ECB (European Central Bank, 2010), the business performance is the ability to generate sustained profit. First of all, profit will be transferred to the contingency fund for unexpected losses, consolidating the capital position and then is used for improving future profit via investments extracted from retained profit.

The concept of "business performance" is often utilized to consider how well resources are allocated in the market. Thus, it can be construed as the success level that an enterprise or a bank achieves when allocating inputs and outputs to meet intended goals.

The business performance is a prerequisite for the healthy operation of a bank in the current context of increasingly keen competition. In order to enhance banking efficiency, it is necessary to analyze and determine the level of efficiency and factors affecting the performance of commercial banks via various analytical methods. Accordingly, it is possible to estimate comprehensively the business performance of commercial banks, boost their competitive advantages, and reduce unexpected risks. According to Nguyễn Việt Hùng (2008), factors affecting the business performance of commercial banks are often divided into two groups: indigenous and exogenous. It is dependent on the specific condition of each bank in each period that those factors will have different impacts on the business performance.

Such exogenous factors as economic development, legal corridor, accessibility to information sources, rivals, etc.; and indigenous factors as competence of bank executives, working capital, business strategies, human resource quality, fixed assets, technology, brand name, bank's seniority and prestige, etc. all have sharp impacts on the business performance of commercial banks. 


\section{METHODOLOGY AND DATASET}

Based on existing studies, both qualitative and quantitative methods are employed to conduct the research.

(1) The qualitative analysis is based on indices and charts.

(2) The quantitative analysis is to identify factors affecting the business performance of commercial banks. Accordingly, the data envelopment analysis (DEA) approach will be employed to estimate the performance of each surveyed bank, and then quantitative analysis will be performed with the Tobit regression method.

(3) The software DEAP 2.1 will be used to test the business performance; and with the support of Stata software, the Tobit regression is performed to identify factors affecting the business performance of commercial banks.

(4) Research data is collated from the SBV, official websites of commercial banks, GSO, Ministry of Finance, IMF, World Bank, and ADB, etc., which was publicized in the period $2007-2011$.

The paper aims to evaluate the business performance of 21 Vietnam's commercial banks in the period 2007 - 2011. In the sample set, there are five state-owned commercial banks and 16 joint-stock ones, which will be taken into account as representatives of Vietnam's commercial banks.

\section{BUSINESS PERFORMANCE OF COMMERICAL BANKS IN VIETNAM}

\section{a. Business Performance of Vietnam's Commercial Banks as Estimated by Index Method:}

Financial indices provide crucial information about financial results and business performance of commercial banks. The analysis of financial indices is based on financial statements of commercial banks publicized within the research period. This is a very traditional analytical method which is popular with Vietnam's commercial banks and researchers. Financial indices will be divided into groups of indicators related to different aspects, such as growth, earnings, liquidity, and risk management.

Index analysis is also reflected in the CAMEL model which is used to evaluate the capital adequacy, assets quality, management machinery, earnings, and liquidity.

The business performance is reflected via various criteria. In this paper, the following analyses based on index method are conducted.

* Analyzing the size of chartered capital of Vietnam's commercial banks 
Table 1: Chartered Capital of Vietnam's Commercial Banks until Dec. 31, 2011 (VND billion)

\begin{tabular}{|c|c|c|c|c|c|c|c|}
\hline \multirow{2}{*}{ No. } & \multirow{2}{*}{ Abbreviation } & \multicolumn{2}{|c|}{ Chartered capital } & \multirow{2}{*}{ No. } & \multirow{2}{*}{ Abbreviation } & \multicolumn{2}{|c|}{ Chartered capita } \\
\hline & & 2010 & 2011 & & & 2010 & 2011 \\
\hline 1 & BIDV & 14,600 & 28,251 & 21 & Habubank & 3,000 & 4,050 \\
\hline 2 & VBARD & 20,709 & 21,103 & 22 & Oceanbank & 3,500 & 4,000 \\
\hline 3 & Vietinbank & 15,173 & 20,230 & 23 & Southernbank & 3,049 & 3,212 \\
\hline 4 & Vietcombank & 13,233 & 19,698 & 24 & DaiABank & 3,100 & 3,100 \\
\hline 5 & Eximbank & 10,560 & 12,355 & 25 & VietABank & 2,937 & 3,098 \\
\hline 6 & Sacombank & 9,179 & 10,740 & 26 & GPBank & 3,018 & 3,018 \\
\hline 7 & SCB & 9,185 & 10,583 & 27 & NamVietBank & 1,820 & 3,010 \\
\hline 8 & $\mathrm{ACB}$ & 9,377 & 9,377 & 28 & Trustbank & 3,000 & 3,000 \\
\hline 9 & Techcombank & 6,932 & 8,788 & 29 & OCB & 2,635 & 3,000 \\
\hline 10 & MB & 7,300 & 7,300 & 30 & BacABank & 3,000 & 3,000 \\
\hline 11 & Maritimebank & 5,000 & 7,000 & 31 & TienphongBank & 3,000 & 3,000 \\
\hline 12 & LienVietPostBank & 3,650 & 6,010 & 32 & WesternBank & 3,000 & 3,000 \\
\hline 13 & SeAbank & 5,335 & 5,335 & 33 & VietBank & 3,000 & 3,000 \\
\hline 14 & Vpbank & 4,000 & 5,050 & 34 & KienLong Bank & 3,000 & 3,000 \\
\hline 15 & SHB & 3,498 & 4,816 & 35 & NamA Bank & 2,000 & 3,000 \\
\hline 16 & MHB & 4,515 & 4,515 & 36 & MDB & 3,000 & 3,000 \\
\hline 17 & Dongabank & 4,500 & 4,500 & 37 & VietCapital Bank & 2,000 & 3,000 \\
\hline 18 & VIB & 4,000 & 4,250 & 38 & SaigonBank & 2,460 & 2,460 \\
\hline 19 & ABBank & 3,831 & 4,200 & 39 & PGBank & 2,000 & 2,000 \\
\hline 20 & HDBank & 3,000 & 4,050 & 40 & BaoVietBank & 1,500 & 1,500 \\
\hline Total & & 157,577 & 198,151 & Tota & & 54,019 & 59,448 \\
\hline
\end{tabular}

Source: Author's calculations based on annual reports from commercial banks in 2011

As Table 1 indicates, the chartered capital of commercial banks is very humble, most of them merely possess a sufficient chartered capital as stipulated by law.

* Analyzing the earnings

The most remarkable point in performance of commercial banks is that their ROA and ROE are on the upward trend, that is, above $1 \%$ for ROA and $10 \%$ for ROE. 
The profitability of Vietnam's banking system in 2011 is at the average level and lower than that of the previous year. Specifically, in 2011, the profit rises $15.1 \%$ compared to 2010; while the growth rate of the owners' equity and the asset size is $22.85 \%$ and $18.55 \%$ respectively.

The two most important indices reflecting the business performance and the return rate of banking institutions are ROA and ROE. The returns on asset and equity in 2011 were lower than those of 2010. Specifically, the ROA and ROE in 2011 were 1.09\% and $11.86 \%$ respectively while these figures in 2010 were $1.29 \%$ and $14.56 \%$ respectively. Compared to ROA and ROE of first-grade listed companies of ten other industries of the economy, the ROE of the banking system is at an average level ( $6^{\text {th }}$ out of ten) and its ROA is the lowest. Noteworthily, there is a big gap in terms of the profit of banks in 2011. The rise in the profit of the entire banking system is mainly because of the growth of several banks possessing tremendous owners' equity and huge assets, along with a good management machinery. Meanwhile, plenty of small-sized banks with poor management and competitiveness, due to their high-interest borrowings and exorbitant rate of bad debts, could not achieve the intended goals of business performance in 2011.

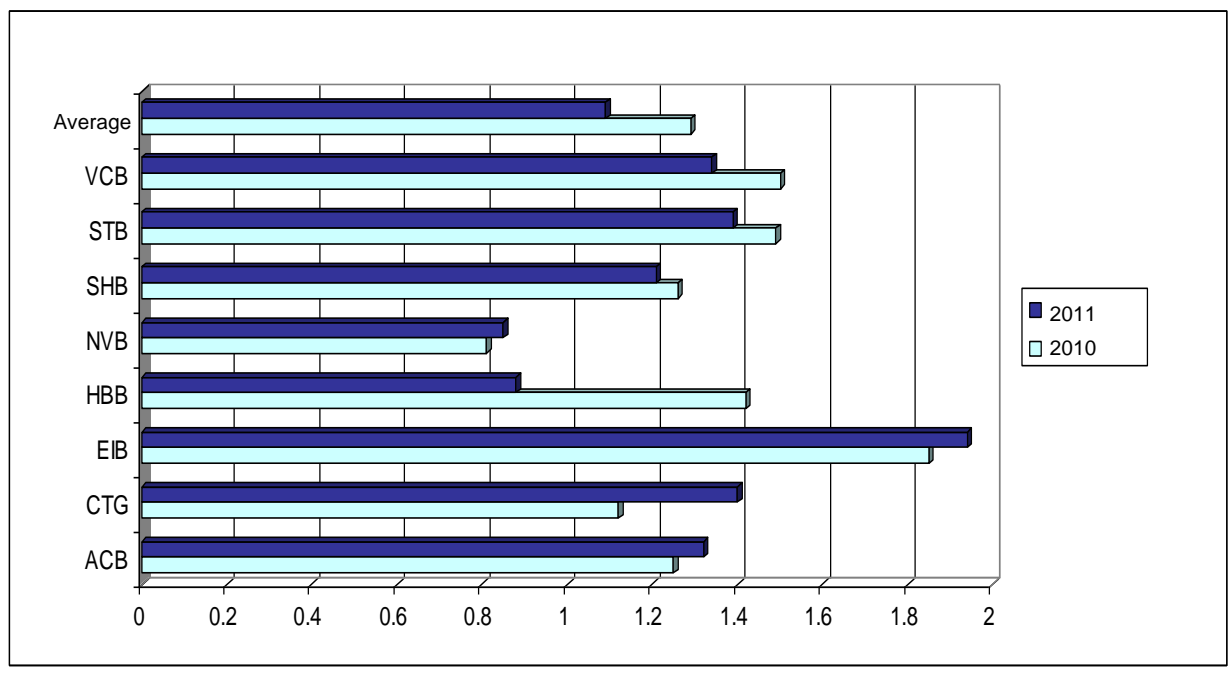

Figure 1: ROA of Listed Banks

Source: Author's calculations based on the financial statements from eight banks in 2010 and 2011 


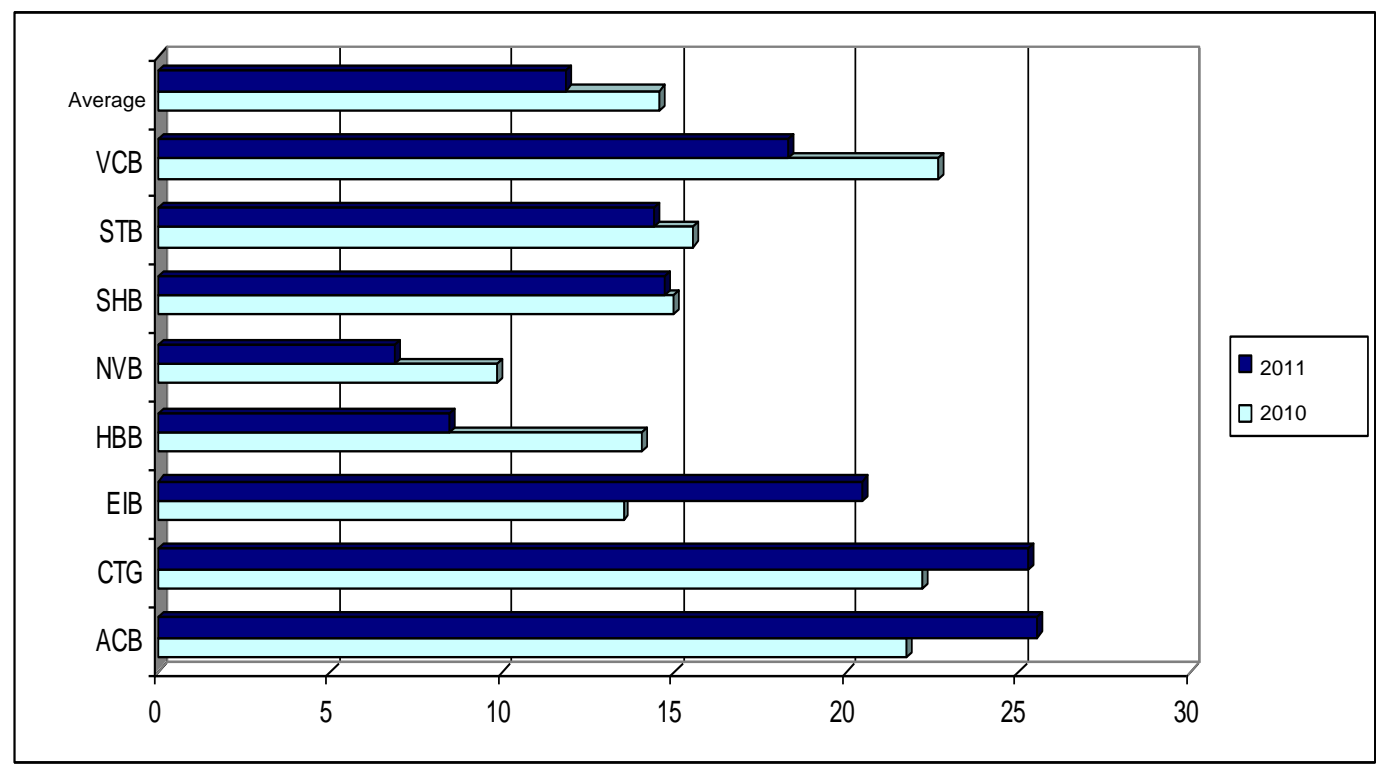

Figure 2: ROE of Listed Banks

Source: Author's calculations based on the financial statements from eight banks in 2010 and 2011

* Analyzing credit quality

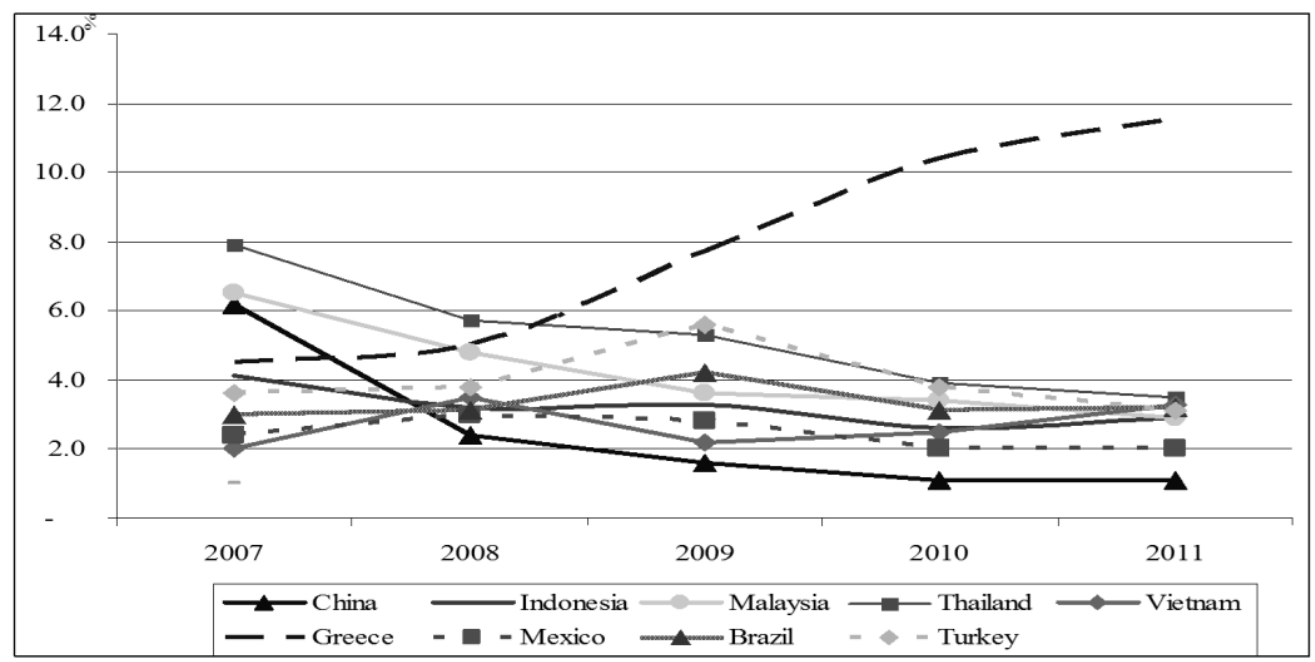

Figure 3: Bad Debt Ratio in Some Developing Countries in the Period 2007 - 2011

Source: Author's calculations based on data uploaded in the website of World Bank and SBV annual reports in $2007-2011$ 
According to analyses by World Bank, while the ratio of bad debts of some Southeast Asian countries (e.g. Malaysia and Thailand) and other developing economies (e.g. Mexico, China, and Turkey) have shown a downward trend in recent years, it has ceaselessly increased in Vietnam since 2008.

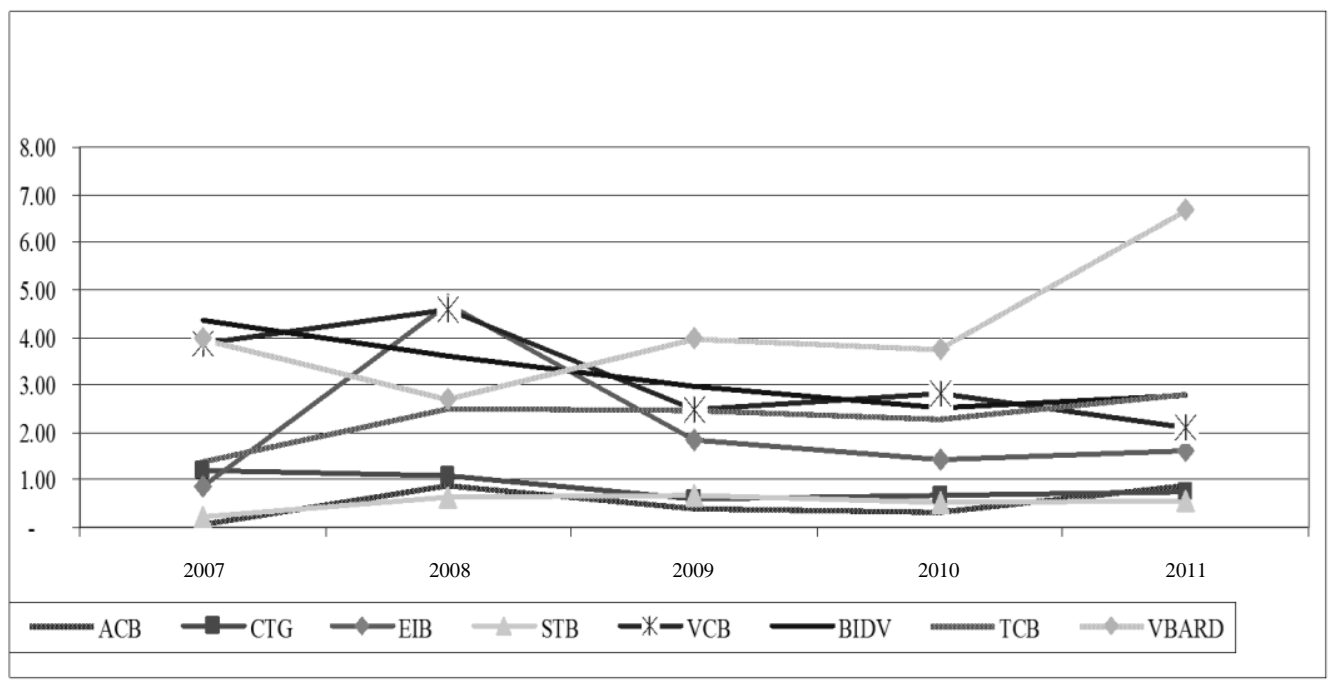

Figure 4a: Bad Debt Ratio of Some Vietnam's Banks in the Period 2007 - 2011

Source: Author's calculations based on financial statements of eight banks in 2007 - 2011

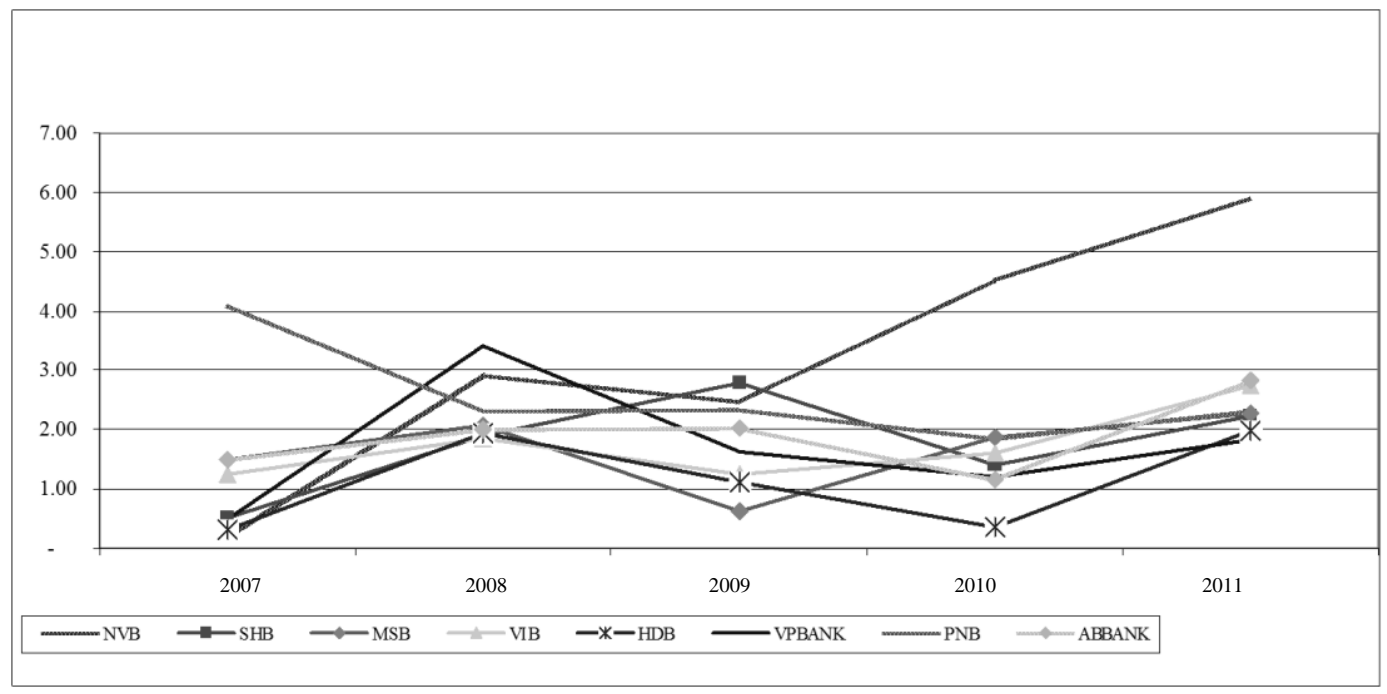

Figure 4b: Bad Debt Ratio of Some Vietnam's Banks in the Period 2007 - 2011

Source: Author's calculations based on financial statements of eight banks in 2007 - 2011 
The bad debt ratio in state-run banks is much higher than that of joint-stock ones. Up to late 2011, the bad debt ratio of VBARD reached 6.7\%, the highest level within the past five years. In the meantime, the bad debt ratio of Vietcombank and BIDV tended to reduce, respectively reaching $2.1 \%$ and $2.8 \%$ which, however, are quite high compared to that of the entire banking system.

* Analyzing the capital adequacy ratio (CAR)

Requirements of the capital adequacy ratio of Vietnam's commercial banks have been gradually amended to meet international standards. This ratio, as provided, must range between 8\% (in accordance with the Decision 457/2005/QĐ-NHNN regarding the Basel I-based capital safety ratio of banking institutions) and $9 \%$ (in accordance with the Circular 13/2010/TT-NHNN concerning the Basel II-based capital adequacy ratio of banking institutions). This requirement keeps putting great pressure on some commercial banks. Majority of banks could ensure the minimum CAR of $9 \%$ in late 2010; and until late 2011 they continue to meet and even exceed this requirement.

Table 2: CAR of Some Banks in the Period 2009 - 2011

\begin{tabular}{lccc}
\hline Bank & $\mathbf{2 0 0 9}$ & $\mathbf{2 0 1 0}$ & $\mathbf{2 0 1 1}$ \\
\hline ACB & 9.97 & 10.6 & 9.25 \\
BIDV & 9.53 & 9.3 & $>10$ \\
CTG & 8.06 & 9.4 & 10.57 \\
EIB & 26.87 & 17.79 & 12.94 \\
SHB & 12 & 13.81 & 13.37 \\
STB & 11.41 & 9.97 & 11.66 \\
TCB & 9.6 & 13.1 & 11.43 \\
VBARD & & 6.14 & 8 \\
VCB & 8.11 & 8.37 & 11.4 \\
\hline
\end{tabular}

Source: Financial statements of nine banks in 2009 - 2011

Given Basel III, CAR is raised up to $13 \%$ per annum to weather economic fluctuations. Some Vietnam's commercial banks can meet it; yet it may be very difficult for small-sized ones to reach this ratio. Therefore, in the context of economic integration, Vietnam's banks should increase their CAR. 
* Analyzing the liquidity

The liquidity of commercial banks has become drearier, as reflected in ceaseless increases in the loan-to-deposit ratio in 2010 while the total deposit seems to decline. Additionally, while this ratio in most Asian countries is less than $80 \%$, it shoots up to $130 \%$ in Vietnam at times. Therefore, the SBV Circular 13/2010/TT-NHNN that came into effect as from October 2010 provides that the maximum ratio is $80 \%$ for banks and $85 \%$ for other banking institutions. However, until late 2011, this ratio has not been adjusted down or thoroughly tackled.

Operation of Vietnam's commercial banks depends heavily on the lending service. However, the loan-to-deposit ratio tended to increase, from $0.95 \%$ in 2008 up to $1.01 \%$ in 2010 and $1.03 \%$ in 2011; and the credit growth rate is higher than the deposit growth rate; which can sharply affect the liquidity of banks.

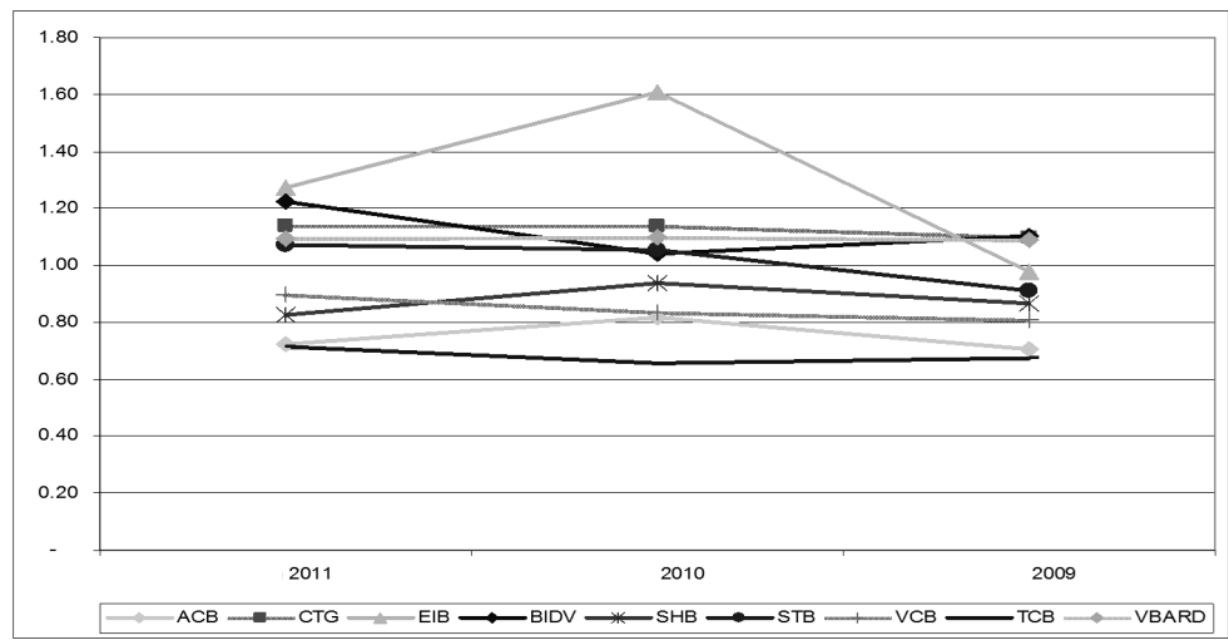

Figure 6: Loan-to-deposit Ratio of Some Major Banks in Vietnam

Source: Author's calculations based on the financial statements of nine banks in 2009 - 2011

As the aforementioned analyses indicate, commercial banks have tried to ensure an adequate chartered capital in accordance with banking regulations, maintain their profitability, and develop their own banking technology. However, their capital is still rather small while their liquidity is volatile, which affects badly their business performance.

If only financial index analyses are taken into account, however, then we can only see the tendency of indices. Such indices merely reflect how inputs are employed to 
generate outputs by commercial banks. They vary at various points of time and may be absolute figures or ratios that express relationship between two specific variables. At present, bank executives have paid more attention to international standards such as CAMEL, which has not been popular in Vietnam because some provisions of CAMEL are hardly quantified.

In order to overcome limitations of the traditional analytical method, researchers and developed banks in the world have also analyzed the marginal efficiency to measure the business performance of commercial banks and its influential factors. This new method extends a more specific view of the business performance of commercial banks.

\section{b. Analyzing Factors Affecting the Business Performance of Vietnam's Commercial Banks Based on Marginal Efficiency:}

Our research is based on previous studies by Rezitis (2006), Pasiouras et al. (2007), Nguyễn Việt Hùng (2008), and Ngo Dang Thanh (2012). Banks will be treated as financial intermediaries and the Tobit model will be employed to evaluate the business performance of Vietnam's commercial banks.

Accordingly, the most popular model employed to estimate the banks' business performance is as follows:

$\mathrm{EF}_{\mathrm{t}}=\mathrm{C}+\alpha_{1}$ LNSIZE $_{\mathrm{t}}+\alpha_{2}$ LNHEADCOUNT $_{\mathrm{t}}+\alpha_{3}$ OWNER $_{\mathrm{t}}+\alpha_{4}$ TE/TA $\mathrm{T}_{\mathrm{t}}+\alpha_{5}$ NPL $_{\mathrm{t}}+$ $\alpha_{6} \mathrm{DLR}_{\mathrm{t}}+\alpha_{7} \mathrm{LNGDP}_{\mathrm{t}}+\alpha_{8} \mathrm{CPI}_{\mathrm{t}}+\varepsilon$

Where:

EF: index to measure the technical efficiency

LNSIZE: logarithm of the total asset

LNHEADCOUNT: logarithm of the workforce

OWNER: dummy variable for the type of commercial bank

TE/TA: ratio of owners' equity to total asset

NPL: ratio of bad debts to total outstanding loan

DLR: ratio of deposit to total outstanding loan

LNGPD: logarithm of per-capita GDP

CPI: consumer price index 
Application of Data Envelopment Analysis (DEA) model and the Tobit model to estimate the performance of commercial banks can be summarized step by step as follows:

Step 1: Identify and collate input and output numerical data from financial statements of commercial banks published within the research period.

Step 2: Perform DEA to calculate efficiency-measuring indicators and evaluate the efficiency of commercial banks.

Step 3: Apply the Tobit regression model to identification of factors affecting the business performance of commercial banks.

Step 4: Extend some solutions for improving the business performance of commercial banks on the basis of analytical results.

* Analyzing estimated constant returns to scale technical efficiency (crste), variable returns to scale technical efficiency (vrste), scale efficiency (se) of various types of banks

Table 3: Estimating crste, vrste and se of Types of Banks in the Period 2007 - 2011

\begin{tabular}{llccccc}
\hline Year & Criteria & Mean & Standard deviation & Min & Max & N \\
\hline \multirow{4}{*}{$\begin{array}{l}\text { Total samples } \\
\text { crste }\end{array}$} & 0.744 & 0.195 & 0.413 & 1.000 & 21 \\
& vrste & 0.841 & 0.168 & 0.529 & 1.000 & 21 \\
& se & 0.887 & 0.143 & 0.435 & 1.000 & 21 \\
\cline { 2 - 6 } & State-owned commercial banks & & & \\
& crste & 0.887 & 0.109 & 0.732 & 1.000 & 5 \\
& vrste & 1.000 & - & 1.000 & 1.000 & 5 \\
& se & 0.887 & 0.109 & 0.732 & 1.000 & 5 \\
\cline { 2 - 6 } & Joint-stock commercial banks & & & \\
crste & 0.700 & 0.197 & 0.413 & 1.000 & 16 \\
& vrste & 0.791 & 0.163 & 0.529 & 1.000 & 16 \\
se & 0.887 & 0.155 & 0.435 & 1.000 & 16
\end{tabular}




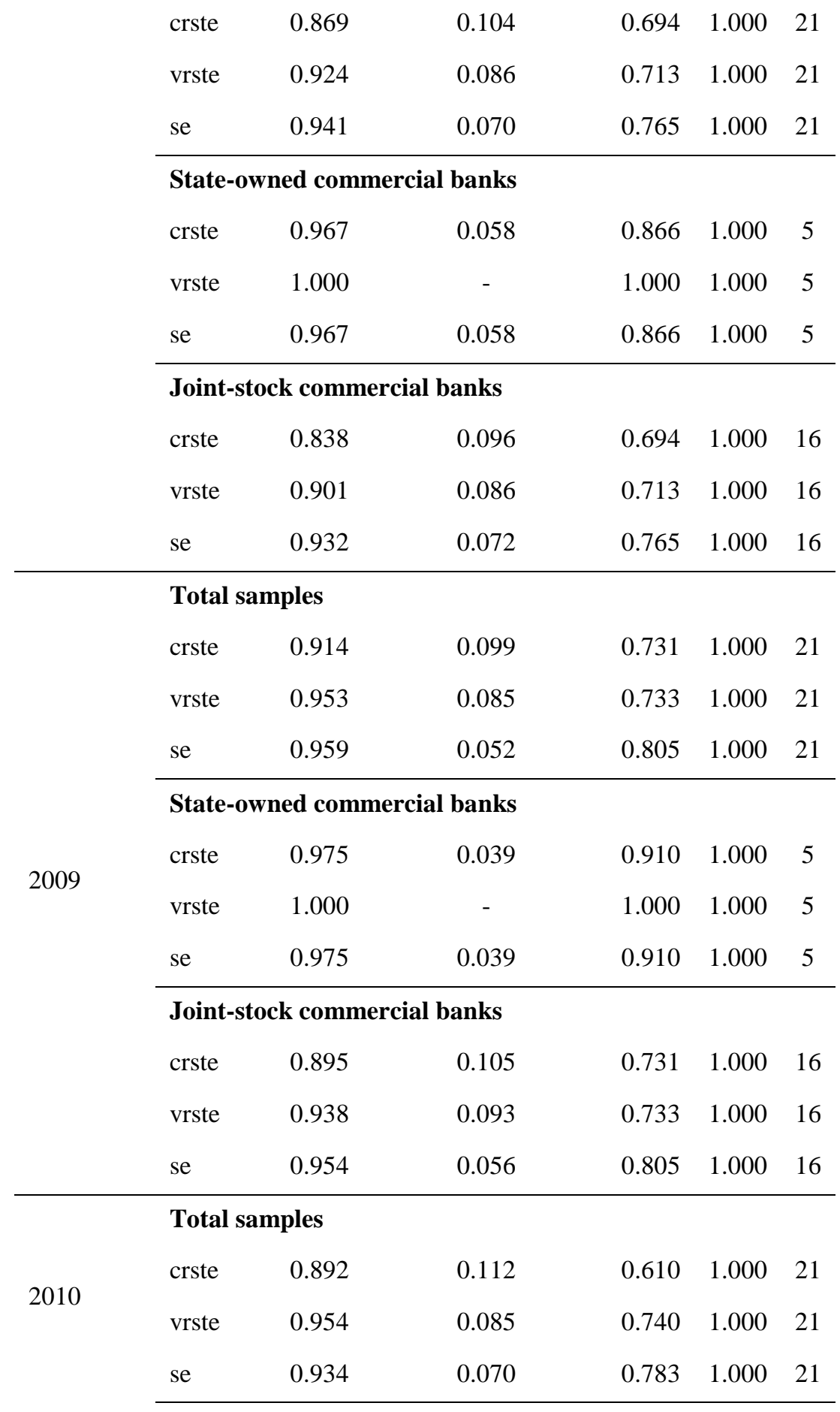




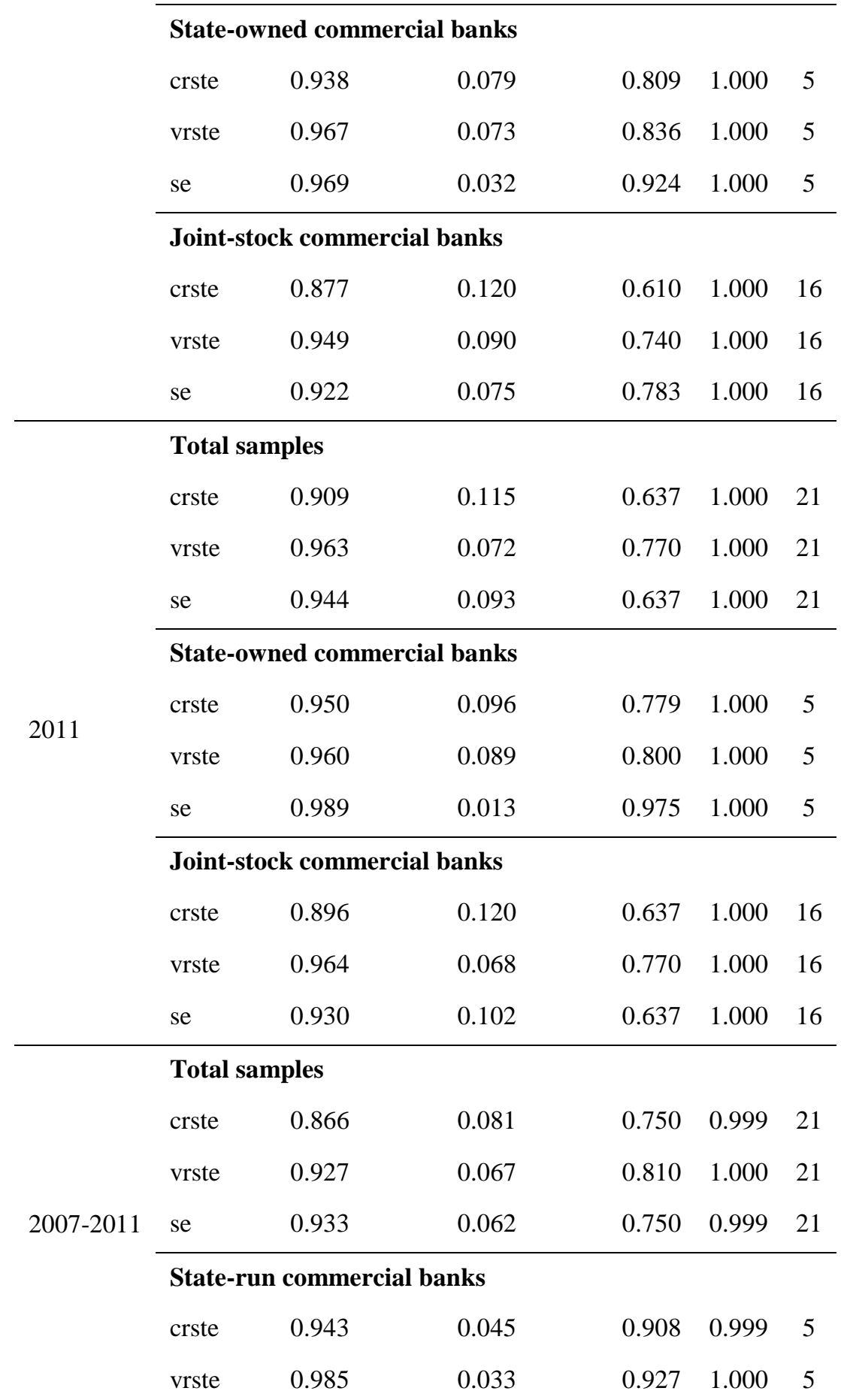




\begin{tabular}{lccccc} 
se & 0.958 & 0.042 & 0.910 & 0.999 & 5 \\
\hline \multicolumn{4}{l}{ Joint-stock commercial banks } \\
crste & 0.841 & 0.074 & 0.750 & 0.952 & 16 \\
vrste & 0.909 & 0.065 & 0.810 & 1.000 & 16 \\
se & 0.925 & 0.066 & 0.750 & 0.994 & 16 \\
\hline
\end{tabular}

Source: Estimates produced by the DEA model

As Table 3 indicates, the average technical efficiency of the entire sample set within the period 2007 - 2011 reaches 0.866 . This implies that Vietnam's commercial banks, in order to produce similar outputs, could only make use of $86.6 \%$ of inputs; or in other words, they are wasting roughly $15.5 \%$ of inputs.

* Analyzing estimates of efficiency and productivity change

Table 4: Estimates of Efficiency Change (effch), Technological Change (techch),

Pure Technical Efficiency Change (pech), Scale Efficiency Change (sech), and Total Factor Productivity Change (tfpch) in the Period 2007 - 2011

\begin{tabular}{ccccccc}
\hline No. & Banks & effch & techch & pech & sech & tfpch \\
\hline 1 & ABBank & 0.924 & 1.007 & 0.925 & 0.999 & 0.931 \\
2 & ACB & 1.036 & 1.027 & 1.048 & 0.989 & 1.064 \\
3 & BIDV & 1.018 & 1.044 & 1.000 & 1.018 & 1.062 \\
4 & CTG & 1.051 & 0.996 & 1.000 & 1.051 & 1.046 \\
5 & EIB & 1.057 & 1.059 & 1.048 & 1.008 & 1.119 \\
6 & HDB & 1.000 & 0.917 & 1.000 & 1.000 & 0.917 \\
7 & MHB & 0.951 & 0.960 & 0.951 & 1.000 & 0.913 \\
8 & MSB & 1.105 & 1.002 & 1.104 & 1.001 & 1.107 \\
9 & NVB & 1.093 & 0.899 & 1.154 & 0.947 & 0.983 \\
10 & OCB & 1.173 & 0.874 & 1.106 & 1.060 & 1.025 \\
11 & PG Bank & 0.957 & 0.969 & 1.000 & 0.957 & 0.928 \\
12 & PNB & 1.096 & 1.020 & 1.107 & 0.990 & 1.118 \\
13 & SHB & 1.048 & 0.984 & 1.038 & 1.010 & 1.032 \\
14 & STB & 1.040 & 1.044 & 1.014 & 1.026 & 1.086 \\
15 & TCB & 1.110 & 1.033 & 1.077 & 1.031 & 1.147 \\
16 & VAB & 1.167 & 0.918 & 1.145 & 1.019 & 1.071
\end{tabular}




\begin{tabular}{lcccccc}
17 & VBARD & 1.075 & 0.924 & 1.000 & 1.075 & 0.993 \\
18 & VCB & 0.999 & 1.023 & 1.000 & 0.999 & 1.021 \\
19 & VIB & 1.033 & 1.067 & 1.020 & 1.013 & 1.103 \\
20 & VPBank & 1.247 & 0.886 & 1.090 & 1.144 & 1.105 \\
21 & WesternBank & 1.100 & 0.888 & 1.000 & 1.100 & 0.976 \\
\hline Mean & $\mathbf{1 . 0 5 8}$ & $\mathbf{0 . 9 7 6}$ & $\mathbf{1 . 0 3 8}$ & $\mathbf{1 . 0 2 0}$ & $\mathbf{1 . 0 3 3}$ \\
\hline
\end{tabular}

Source: Estimates produced by the DEA model

As Table 4 indicates, estimates of changes in efficiency and productivity of each bank in the period 2007 - 2011 reflect quite appropriately its business performance. Banks with strong brand names and great market shares perform kind of efficiently (e.g. BIDV, VCB, ACB, CTG, EIB, MSB, PNB, SHB, STB, TCB, VIB).

5. TESTING THE TOBIT REGRESSION MODEL OF FACTORS AFFECTING THE BUSINESS PERFORMANCE OF VIETNAM'S COMMERCIAL BANKS

Table 5: Testing Results of the Tobit Regression Model of Factors Affecting the Business Performance of Vietnam's Commercial Banks

\begin{tabular}{lcccccc}
\hline \multicolumn{1}{c}{ Variables } & Coefficient & $\begin{array}{c}\text { Standard } \\
\text { error }\end{array}$ & $\mathbf{t}$ & $\mathbf{P}>|t|$ & \multicolumn{2}{c}{$\begin{array}{c}\text { Confidence interval = } \\
\mathbf{9 5 \%}\end{array}$} \\
\hline LNSIZE & 0.142306 & 0.038562 & 3.69 & 0.000 & 0.065771 & 0.218841 \\
LNHEADCOUNT & -0.13002 & 0.041685 & -3.12 & 0.002 & -0.21275 & -0.04728 \\
OWNER & 0.081347 & 0.043372 & 1.88 & 0.044 & -0.00473 & 0.167429 \\
TE/TA & 0.064091 & 0.273898 & 0.23 & 0.815 & -0.47952 & 0.607703 \\
NPL & -0.02136 & 0.010482 & -2.04 & 0.044 & -0.04216 & -0.00055 \\
DLR & -0.13255 & 0.046868 & -2.83 & 0.006 & -0.22557 & -0.03953 \\
LNGDP & 0.587317 & 0.631099 & 0.93 & 0.354 & -0.66524 & 1.839874 \\
CPI & -0.00508 & 0.003949 & -1.29 & 0.202 & -0.01291 & 0.002761 \\
CONS & -2.79112 & 3.812577 & -0.73 & 0.466 & -10.358 & 4.775796 \\
\hline
\end{tabular}

Source: Estimates produced by the Tobit model

Such factors as asset size, workforce, ratio of owners' equity to total assets, bad debt ratio, and loan-to-deposit ratio, etc. can explain $32.77 \%$ of the technical efficiency. 
Table 5 indicates that "total asset" has positive impacts on the business performance of banks, which is reflected by the sign and value of the regression coefficient of LNSIZE ( $\alpha_{1}=0.142306$ ). This finding is reliable because of $t=3.69, p=0.000$, the reliability of over $95 \%$, and the positive sign of both upper and lower bounds. Thus, the bank's total asset can help enhance the business performance. According to the model results, if the variable "total asset" rises by a unit, the technical efficiency will rise $14.23 \%$.

Similarly, the bank's workforce also affects the business performance. With $\alpha_{2}=-$ $0.13002, p=0.002$ and negative upper and lower bounds, the workforce increasing faster than the bank's growth will create a waste of human resources; and the rise in labor cost will affect the bank's profit.

The estimate coefficient of OWNER (type of commercial bank) also shows its impacts on the business performance. With $\alpha_{3}=0.081347$, OWNERNN or the stateowned commercial bank positively affects the business performance. However, this conclusion cannot be applied to all banks.

As for the ratio of total owners' equity to total asset (TE/TA), if this ratio rises by $1 \%$, the business performance will increase $6.4 \%$. However, it is unreliable due to its low reliability. The model cannot assert impacts of this factor; and thus there needs to be a broader research to determine the influential level of this factor.

Results from the Tobit model show that estimate coefficient $\alpha_{5}$ of the ratio of bad debts to total outstanding loans (NPL) equals -0.02136. This implies that if the bad debt ratio increases one unit, the business performance will decrease $2.13 \%$; or in other words, the higher the bad debt ratio, the lower the business performance and vice versa.

Bearing a negative sign $\left(\alpha_{6}=-0.13255\right)$ as expected, the ratio of deposit to total outstanding loan (DLR) has negative impacts on the technical efficiency with the statistical significance $\mathrm{p}$-value $=0.006$. The upper and lower bounds are also negative (i.e. -0.22557 and -0.03953 respectively). This can be comprehensible that if banks manage well their deposits, the business performance will rise accordingly.

The GDP is unreliable because signs of its upper bound (1.839874) and lower bounds $(-0.66524)$ are opposite. The sign of the regression coefficient $\left(\alpha_{7}=0.587317\right)$ is positive as expected; and thus it is meant that if GDP rises a unit, it may affect the business performance at the point of 58.73\%. Yet, it is not applicable to the whole banking system due to the low reliability. 
Similarly, the sign of the estimate coefficient of CPI $\left(\alpha_{8}=-0.00508\right)$ is negative as expected. Accordingly, the higher the CPI, the lower the business performance. Yet with $\mathrm{t}=-1.29, \mathrm{p}=0.202$, and the opposite signs of the lower and upper bounds, it implies that $\mathrm{CPI}$ has negative impacts on the business performance at low reliability. Therefore, to assert influence of this variable requires broader researches.

In sum, appropriate variables with high reliability which can represent the whole system include the size of total asset, the workforce, the bad debt ratio, and the ratio of deposit to total outstanding loan. Of them, the total asset with the largest regression coefficient $\alpha_{1}$ equaling 0.142306 has the most positive impact on the business performance.

\section{SOME SUGGESTIONS FOR IMPROVEMENT IN BUSINESS PERFORMANCE OF VIETNAM'S COMMERICAL BANKS}

Through the aforementioned analytical results, it is possible to extend several suggestions for improvement in business performance of Vietnam's commercial banks:

Firstly, Vietnam's commercial banks should employ various methods of business performance evaluation.

In order to estimate the business performance, banks should make use of various evaluation methods because each method has its own strengths and weaknesses. In addition to using traditional methods (e.g. financial indices-based method that has been thus far employed by Vietnam's commercial banks), they should attend to modern ones such as DEA approach and Tobit regression model with a view to exploring different aspects of the results and opting for the most appropriate method.

Secondly, factors affecting the business performance should be thoroughly heeded.

Given the financial indices-based analytical results and the Tobit regression ones, it is apparent that both endogenous and exogenous factors have impacts on the business performance of commercial banks. Hence, it is suggested that commercial banks should weigh up influential factors when analyzing the business performance.

Specific suggestions related to the improvement in the business performance of commercial banks are as follows:

- Monitor the credit quality

From the perspective of the banks, the existence of bad debts is due to loose credit policies, ineffective management of credit risks, and corrupt practices of bank tellers. 
Hence, it is necessary to split the lending procedure into independent stages, such as customer contact, customer evaluation, mortgaged asset valuation, and after-lending inspections, etc. to minimize corrupt practices.

Within credit practices, information is the most important input for banks to approve lending. Thus, it is needed to establish a supply of adequate and transparent information about, or track record of, each customer who has had transactions with banking institutions to help other institutions make decision on lending. In addition, it is also advised to employ state-of-the-art software to gather and store information about customers and markets, and establish a credit rating system. Accordingly, it is not only a basis for decision on lending but also a good way to reduce the lending-decision time.

- Ensure accurate, adequate and transparent information

In order to apply DEA and Tobit regression model to evaluation of business performance and identification of influential factors, it is necessary to ensure sources of accurate, adequate and transparent information to achieve highly statistical significant and reliable results.

- Enhance the financial competence

Given the regression results, the financial strength has impacts on the business performance of Vietnam's commercial banks within the research period. Therefore, enhancing the financial competence will improve the business performance. The financial competence reflects itself in the following capital criteria:

(i) Size of equity capital: A bank with a huge equity capital can offer peace of mind to customers when selecting a bank to do their business. Moreover, equity capital can shield the bank from risks. In the context of economic integration, banks must plan to increase capital, which will help them fight against risks and take advantage of competitive edges.

(ii) Size of deposits: Deposits are the primary source of capital to facilitate the bank's healthy operation and supply of investments and loans. Hence, deposit size determines credit and investment practices, enable to enhance the profit and expand the equity capital.

(iii) Size of loan capital: It reflects the bank's ability to borrow capital. A bank with good financial strength can easily borrow capital and utilize borrowings for other investment plans. 
The big scale will be an advantage for banks. Yet, it is advised to avoid increasing capital at any price or using it ineffectively.

- Enhance the quality of banking human resources

Human resources are always the key factor in all activities. Through the Tobit model results, the negative sign of the workforce shows that the bank's business performance will be affected if its workforce increases faster than the bank's growth rate. In the current market economy, banking technologies, machinery, products and services are quite identical; and thus the human resource quality will be the keynote and decisive factor for the success of the bank.

- Diversify and promote utility of products and services on the basis of improvement in technological competence

Employment of IT is considered the main trend in the operation of a modern bank. It plays a crucial role in boosting the bank's competitiveness via diversification of products and services in terms of quality and quantity. As the Malmquist indices table indicates, the technological advancement in the period 2007 - 2011 reaches $97.6 \%$ on average, higher than that in the period $2001-2005$. This is to say, IT has been more and more employed in banking operations. Given experiences of foreign banks, IT can reduce $76 \%$ of operational cost for banks, and thereby enhancing the business performance.

- Boost the ability to manage risks and monitor banking operations

The finance market, and banking service as well, has its own systematic risks. Hence, risks management has been more and more heeded in banks. Risks management, despite often established on the basis of international conventions, must be congruent with the actual finance market in Vietnam. Establishment of a comprehensive risk management system must aim to management of credit risks, liquidity risks, interest rate risks, and exchange rate risk, etc.

Auditing must be done properly to ensure the safe operation of the bank in particular and the whole banking system in general. It is also necessary to enhance the internal inspection so as to timely identify potential risks and minimize losses. However, it is not advised to observe mechanically principles of internal inspection, which can hinder the creativity. Changing situations require flexible inspection and management. Auditors and internal inspectors should be trained professionally, have sense of responsibility, and updated knowledge about banking regulations and applicable laws. 
In this paper, financial indices-based analyses are based on numerical data from Vietnam's commercial banks up to 2011. The factor analyses are constrained in terms of the sample size and research period (i.e. 21 commercial banks within five years), the number of input and output variables used for DEA (i.e. three inputs and two outputs), and the number of endegenous and exogenous variables (i.e. six endogenous variables and two exogenous ones); thus the statistical significance and the reliability of some influential factors are limited. In further research, it is advised to increase the sample size, the research period and the number of input and output variables, endogenous and exogenous variables to enhance the model significance and reliability.

Suggestions of the present paper are merely related to factors affecting the business performance; and it can serve as a prerequisite for further researches

\section{References}

Châu Thị Minh Hà \& Phạm Lê Thông (2011), "Hiệu quả kỹ thuật của các ngân hàng thương mại Việt Nam”, Công nghệ Ngân hàng, No.69.

Coelli, T. (2008), A Guide to DEAP Version 2.1: A Data Envelopment Analysis (Computer) Program, CEPA Working Paper 96/08, Center for Efficiency and Productivity Analysis, Department of Econometric, University of New England.

IzahMohdTahir \& Ku NarainiChe Ku Yusof (2011), "Estimating Technical and Scale Efficiency of Malaysian Public Listed Companies: A Non-Parametric Approach”, Interdisciplinary Journal of Research in Business, Vol.1, Iss.7, pp.01-07.

Jemric, Igor \& Boris Vujcic (2001), "Efficiency of Banks in Transition: A DEA Approach", Current Issues in Emerging Market Economies, Croatian National Bank.

Liễu Thu Trúc \& Võ Thành Danh (2012), "Phân tích hoạt động kinh doanh của hệ thống ngân hàng thương mại cổ phần Việt Nam”, Khoa học, No.21a, pp.158-168, Cần Thơ University.

Moradi-Motlagh, A., A. Saleh, A. Abdekhodaee \& M. Ektesabi (2011), "Efficiency, Effectiveness and Risk in Australian Banking Industry”, World Review of Business Research Vol.1, No.3, pp.112.

Ngo Dang Thanh (2012), "Measuring the Performance of the Banking System, Case of Vietnam (1990-2010)", Journal of Applied Finance \& Banking, Vol.2, No.2, pp.289-312.

Ngo Dang Thanh (2010), Evaluating the Efficiency of Vietnamese Banking System: An Application Using Data Envelopment Analysis, MPRA Paper No. 27882.

Nguyễn Khắc Hoàn (2010), "Sử dụng mô hình Tobit trong phân tích nhu cầu tiêu thụ hàng hóa của các hộ gia đình”, Khoa học, No.60. Huế University. 
Nguyễn Trường Sơn \& Nguyễn Thị Hạnh (2011), "Đánh giá ảnh hưởng của R\&D đối với kết quả kinh doanh của doanh nghiệp bằng mô hình DEA”, Khoa học và Công nghệ, Vol.1(42), Đà Nẵng University.

Nguyễn Việt Hùng (2008), "Phân tích các nhân tố ảnh hưởng đến hiệu quả hoạt động của các ngân hàng thương mại Việt Nam", unpublished doctoral thesis, University of National Economy, Hà Nội.

Pasiouras, F., E. Sifodaskalakis \& C. Zopounidis (2007), Estimating and Analyzing the Cost Efficiency of Greek Cooperative Banks: An Application of Two-Stage Data Envelopment Analysis, Working Paper Series, University of Bath, School of Management.

Phạm Thị Bích Lương (2007), "Giải pháp nâng cao hiệu quả hoạt động của các ngân hàng thương mại nhà nước Việt Nam hiện nay”, unpublished doctoral thesis, University of National Economy, Hà Nội.

Rezitis, A.N. (2006), "Productivity Growth in the Greek Banking Industry: A Non - Parametric Approach", Journal of Applied Economics, Vol. IX, No.1, pp.119-138.

Tô Ngọc Hưng \& Nguyễn Đức Trung (2011), "Hoạt động ngân hàng Việt Nam- Nhìn lại năm 2011 và một số giải pháp cho năm 2012”, Khoa hoc \& Đào tạo Ngân hàng, No 118, pp. 1-7.

Yudistira, D. (2004), "Efficiency in Islamic Banking: An Empirical Analysis of Eighteen Banks", Islamic Economic Studies, Vol.12, No.1.

Yue, P. (1992). "Data Envelopment Analysis and Commercial Bank Performance: A Primer with Applications to Missouri Banks.” Federal Reserve Bank of St. Louis Economic Review, Vol.74(1), pp.31-45. 